\title{
Characterization of Monoolein-Based Lipoplexes Using Fluorescence Spectroscopy
}

\author{
J. P. Neves Silva • P. J. G. Coutinho • \\ M. E. C. D. Real Oliveira
}

Received: 31 October 2007 / Accepted: 29 November 2007 /Published online: 23 December 2007

(C) Springer Science + Business Media, LLC 2007

\begin{abstract}
Lipoplexes are commonly used as delivery systems in vitro and in vivo, the role of a neutral lipid as helper being of extreme importance in these systems. Cationic liposomes composed of dioctadecyldimethylammonium bromide (DODAB) with monoolein (MO) as a helper, at different molar ratios $(1: 2 ; 1: 1$ and 1:0.5) were prepared, and subsequently titrated to DNA. The structural and physicochemical properties of the lipid/DNA complexes were assessed by ethidium bromide (EtBr) exclusion, $90^{\circ}$ static light scattering $\left(90^{\circ}\right.$ SLS) assays and fluorescence resonance energy transfer (FRET). In EtBr exclusion assays, the steady-state fluorescence spectra of $\mathrm{EtBr}$ were decomposed into the sum of two lognormal emissions, emanating from two different environments $\mathrm{H}_{2} \mathrm{O}$ and DNA, and the effect of charge ratio (+/-) was observed. $90^{\circ}$ SLS assays gave an important contribution, detecting size variations in systems with different $\mathrm{MO}$ fractions on the lipoplexes. In FRET assays, 2-(3-(diphenylhexatrienyl)propanoyl)-1-hexadecanoyl-sn-glycero-3-phosphocholine (DPH-HPC) was used as donor and EtBr as acceptor. The DNA component previously calculated by $\mathrm{EtBr}$ exclusion, was used to determine the energy transfer efficiency, as an indirect measurement of the lipoplexes structural and physicochemical properties. Our results demonstrate that the inclusion of monoolein in the cationic liposomes formulation significantly modifies the rate of DNA complexation, being DODAB:MO (1:1) the system with higher DNA condensation efficiency.
\end{abstract}

J. P. N. Silva • P. J. G. Coutinho • M. E. C. D. R. Oliveira $(\triangle)$

Physics Department, University of Minho,

Campus of Gualtar,

4710-057 Braga, Portugal

e-mail: beta@fisica.uminho.pt
Keywords Monoolein-based lipoplexes · EtBr exclusion · FRET $\cdot 90^{\circ}$ SLS

\section{Introduction}

The absence of vectors, viral or non-viral, that efficiently condense and release DNA in the target-cells is presently considered the major limitation for the expansion of gene therapy [1]. DNA, when complexed with cationic liposomes, can be used as a non-viral vector [2]. Due to electrostatic interaction, cationic lipids spontaneously associate with DNA by a process of self-assembly, resulting in the formation of cationic lipid-DNA complexes, so-called lipoplexes [3]. These membranous structures are capable of transducing genes into cells, eventually leading to their expression by a process called transfection [4]. Despite of the intensive interest in these systems, namely in the relationship between their biophysical features and the mode of interaction with the cells, it is still not possible today to predict clearly the implication of the physical properties on the efficiency of gene transfer, and the factors involved in this process [5]. Apart from their low transfection efficiencies, lipoplexes are non-imunogenic structures that present low citotoxicity and high potential for large-scale production [6].

In the last two decades, a high number of studies has been published regarding the optimization of lipid formulations and the measurement of the transfection efficiency as a function of several parameters such as the nature of the cationic surfactant [7], the lipid/DNA charge ratio (+/-) [8,9], the electrostatic properties of the lipoplexes during and after their formation [10], the size of the systems [11, 12], the efficiency of complexation of the DNA [13, 14], and the effect of the presence of additives such as serum [15]. More recently, it has been stated that the inclusion of certain 
neutral lipids (also known as adjuvants or helper) in the liposomal formulation facilitates the fusion of the complexes with the cell membranes, due to its propensity to form nonbilayer structures like hexagonal or cubic phases, which are akin to membrane fusion intermediates [16-17].

In this study, it is explored the effect of monoolein (MO) on the structural and physicochemical properties of dioctadecyldimethylammonium bromide (DODAB)/DNA complexes. The long-chain cationic surfactant DODAB is a synthetic lipid, which in the presence of excess water and above the phase transition temperature $L_{\alpha}-L_{\beta}$, tends to form large unilamellar vesicles (LUV's) [18]. The structural organization of these vesicles depends on the lipid concentration, the method of preparation, the solvent composition, the temperature and the presence of other substances [18]. Monoolein, 1-monooleoyl-rac-glycerol, is an amphiphilic neutral lipid of natural origin that has the particularity of presenting two inverted bicontinuous cubic phases, even in excess water $(<90 \% \mathrm{w} / \mathrm{w})$ [19]. Although monoolein has never been used before for gene therapy purposes, its extremely rich diversity of non-lamellar phases represents, per se, a significant motive for the study of the influence of this molecule on the lipoplexes final features.

Fluorescence spectroscopy remains as the preferential technique for evaluating the lipoplexes physicochemical properties, since it allows the monitoring of several structural changes in the lipoplexes, namely the ones caused by phenomenon's such as vesicle leakage, membrane fusion and hydrophobic exposure [20].

The use of DNA intercalating agents such as ethidium bromide $(\mathrm{EtBr})$ offers a rapid and sensitive way of analysing the lipoplex formation, since they allow the determination of the efficiency of DNA condensation. On DNA complexation at increasing cationic lipid concentration, an overall decrease in EtBr fluorescence intensity is measured, since the intercalating probe is progressively expelled to the external media, where its fluorescence quantum yield is significantly inferior (this decrease is accompanied by a red shift in the probe emission spectra) [21]. Fluorescence resonance energy transfer (FRET) is another technique that is increasingly gaining importance as a method for studying the mechanisms and barriers involved in non-viral gene therapy.

A change in conformation on condensing DNA leads to a change in the distance between two fluorophores, which can be demonstrated through the random double labelling of DNA for FRET [22] or double labelling of the DNA and carriers [23].

As a complementary approach, it have also been used in this study $90^{\circ}$ static light scattering $\left(90^{\circ}\right.$ SLS) assays, with the purpose of determining size variations during the formation of the lipoplexes. The light scattering is weighted by the intensity of scattered light that varies according to diameter of the particle, thus providing direct information about the structure of the complexes [24].

\section{Materials and methods}

Reagents

Monoolein, 1-monooleoyl-rac-glycerol (MO) was purchased from Sigma-Aldrich. DODAB was purchased from Tokyo Kasei. Salmom sperm DNA was purchased from Invitrogen. The intercalating probe ethidium bromide $(\mathrm{EtBr})$ and the lipid probe 2-(3-(diphenylhexatrienyl)propanoyl)-1-hexadecanoyl-sn-glycero-3-phosphocholine (DPH-HPC) were purchased from Molecular Probes. All reagents were used in the same conditions as received.

\section{Liposomes preparation}

For preparing the liposome solutions, defined volumes from the stock solutions of DODAB and MO in ethanol $(20 \mathrm{mM})$ were injected under vigorous vortexing to an aqueous buffer solution at $70{ }^{\circ} \mathrm{C}(30 \mathrm{mM}$ Trizma), so that the final lipid concentration ([DODAB more MO]) was $1 \mathrm{mM}$ and the different DODAB: MO molar ratios (1:2, 1:1, and 1:0.5) were obtained.

\section{Lipoplexes preparation}

Lipoplexes were prepared in a cuvette by adding increasing volumes of the cationic liposome solutions into $2.5 \mathrm{ml}$ of salmon sperm DNA solution $(20 \mu \mathrm{g} / \mathrm{ml})$.

The concentration of nucleotide bases (determined by the DNA absorption at wavelength $260 \mathrm{~nm}$ [25]), was held constant at $4.2 \times 10^{-5} \mathrm{M}$ in all experiments. The charge ratio $(+/-)$ is an indicator of balance between positive charges (given by the concentration of ammonium groups present in DODAB) and negative charges (given by the concentration of phosphate groups in DNA, which corresponds to nucleotide concentration):

C.R. $=\frac{[+]}{[-]}=\frac{[\text { DODAB }]}{[\text { phosphate }]}$

Throughout the titration, charge ratio (+/-) varied constantly, not only due to the addition of the cationic vesicles to the DNA, but also due to the dilution effect originated by it.

For $\mathrm{EtBr}$ exclusion assays, an $\mathrm{EtBr}$ aqueous solution $\left([\mathrm{EtBr}]=7.0 \times 10^{-6} \mathrm{M}\right)$ was added to the DNA solution, leading to the intercalation of the probe. EtBr concentration was kept six times lower than that of the DNA, in order to guaranty a directly proportional decrease in the probe fluorescence to the amount of cationic lipid at a given nucleotide base concentration [26].

In case of FRET assays, for which the presence of the lipid probe DPH-HPC was required ([DPH-HPC $]=1 / 200 \times[$ lipid] $)$, the probe was initially inserted within the lipid solution, and only then injected under vigorous vortexing to an aqueous buffer solution at $70{ }^{\circ} \mathrm{C}(30 \mathrm{mM}$ Trizma), in order to form the 
marked liposome solutions. The preparation of the lipoplexes then followed the same steps described above, that included their addition to the initial DNA solution.

Ethidium bromide exclusion assays

The steady-state fluorescence measurements were performed in a Horiba Jobin Yvon Spex Fluorolog-3 spectrofluorimeter, after each addition of cationic liposomes to the DNA solutions, and a $5 \mathrm{~min}$ agitation period with a magnetic stirrer. The fluorescence intensities were determined at $\lambda_{\mathrm{exc}}=510 \mathrm{~nm}$, because this wavelength is known to be an isobestic point for $\mathrm{EtBr} / \mathrm{DNA}$ solutions [27]. All emission spectra were integrated, and the ratio of the areas for the dye solutions and the standard was determined, after subtraction of the solvent background. Each fluorescence emission spectrum was fitted to a sum of two log-normal functions [28], corresponding to different environment states (DNA and $\mathrm{H}_{2} \mathrm{O}$ ), and had the following form:

$I_{F}=\left(\frac{I_{F}^{\max } \cdot b}{\lambda-a}\right) \cdot e^{-c^{2}-\frac{(\ln (x-a)-\ln (b))^{2}}{2 \cdot c^{2}}}$

where $I_{F}^{\max }$ is the maximum emission intensity at wavelength $\lambda_{\max }$, and the parameters $a, b$, and $c$ are related to $\lambda_{\max }$, halfwidth $(H)$, and skewness $(\rho)$ by the expressions:

$a=\lambda_{\max }-\left(\frac{H \cdot \rho}{\rho^{2}-1}\right) \quad b=\left(\frac{H \cdot \rho}{\rho^{2}-1}\right) \cdot e^{\left(\frac{\ln (\rho)}{\sqrt{2 \cdot \ln (2)}}\right)^{2}}$

$c=\frac{\ln (\rho)}{\sqrt{2 \cdot \ln (2)}}$

The area $(A)$ of each curve is given by:

$$
\begin{aligned}
& A=I_{F}^{\max } . \\
& H \cdot\left[(\sqrt{2 \cdot \pi}) \cdot\left(\frac{\rho}{\rho^{2}-1}\right) \cdot\left(\frac{\ln (\rho)}{\sqrt{2 \cdot \ln (2)}}\right) \cdot e^{\left.\frac{\left(\frac{\ln (\rho)}{\sqrt{2 \cdot \ln (2)}}\right)^{2}}{2}\right]}\right]
\end{aligned}
$$

Assuming that the quantum yield of EtBr in the lipoplex remains approximately constant throughout the titration, the percentage of complexed DNA $(\alpha)$ can be determined from the spectral decomposition previously made:

$\alpha=\frac{\int I_{F}^{D N A} \text { band }(C . R .(+/-)=0.0)-\int I_{F}^{D N A \text { band }}(C . R .(+/-)=x)}{\int I_{F}^{D N A} \text { band }(C \cdot R \cdot(+/-)=0.0)} \cdot 100$

Fluorescence resonance energy transfer assays

The steady-state fluorescence measurements were performed in a Horiba Jobin Yvon Spex Fluorolog-3 spectrofluorimeter, after each addition of cationic liposomes to the DNA solutions, and a $5 \mathrm{~min}$ agitation period with a magnetic stirrer. The fluorescence intensities of the lipoplexes labeled with DPH-HPC were determined at $\lambda_{\text {exc }}=390 \mathrm{~nm}$ with spectral bandwidths of $1 \mathrm{~nm}$, in the presence and absence of EtBr. All emission spectra were integrated, and the ratio of the areas for the dye solutions and the standard was determined, after subtraction of the solvent background. The fluorescence resonance energy transfer efficiency $\left(\Phi_{F R E T}\right)$ was determined from the following expression:

$$
\begin{gathered}
\Phi_{F R E T}=1-\left(\frac{\Phi_{D A}}{\Phi_{D}}\right) \Leftrightarrow \Leftrightarrow \Phi_{F R E T}=1-\frac{\left(\frac{I_{F(D A)}}{I_{F(D)}}\right)-\alpha}{1-\alpha} \\
\Leftrightarrow \Phi_{F R E T}=\frac{1-\left(\frac{I_{F(D A)}}{I_{F(D)}}\right)}{1-\alpha}
\end{gathered}
$$

Where $I_{F(D A)}$ and $I_{F(D)}$ are the fluorescence emission of donor (DPH-HPC) in the presence and absence of acceptor $(\mathrm{EtBr})$, respectively. $\alpha$ is the efficiency of complexation of DNA previously determined in EtBr exclusion assays (Eq. 5), which determines the amount of $\mathrm{EtBr}$ (acceptor) that remains in the lipoplex and is able to receive excitation energy from the DPH-PC donor.

$90^{\circ}$ static light scattering assays

$90^{\circ}$ SLS due to the formation of complexes by the cationic liposomes and DNA was measured with a Horiba Jobin Yvon Spex Fluorolog-3 spectrofluorimeter with excitation and emission monochromators set respectively at 600 and $601 \mathrm{~nm}$, at which there is neither absorbance, nor fluorescence emission. Scattering intensities were measured $5 \mathrm{~min}$ after the addition of cationic liposomes in different conditions (presence $(D)$ and absence $\left(D_{0}\right)$ of DNA) and remained constant after this period. The ratio $D / D_{0}$ was determined.

\section{Results \& discussion}

Ethidium bromide exclusion assays

Ethidium bromide (EtBr) is a well-known fluorescence fluorophore that, when intercalated between base-pairs of DNA double helix, presents a high fluorescence emission at $610 \mathrm{~nm}$ (excitation at $500 \mathrm{~nm}$ ), compared to its fluorescence in water [21]. During condensation of DNA after the addition of cationic lipid, varying amounts of $\mathrm{EtBr}$ are forced to dissociate from DNA and go into the aqueous phase resulting in a decrease in the total fluorescence intensity [21].

Figure 1 shows the fluorescence spectra of $\mathrm{EtBr}$ for the system DNA-DODAB:MO (1:1), at the charge ratios (+/-) of $0.0,0.5$., 1.1 and 1.8. With charge ratio $(+/-)$ increase, it is visible a decrease in the DNA band as opposed to the 
Fig. 1 Fluorescence emission spectra of $\operatorname{EtBr}\left(\lambda_{\text {exc }}=510 \mathrm{~nm}\right)$ in a salmon sperm DNA solution ([phosphate $]_{\text {initial }}=4.2 \times 10^{-5} \mathrm{M}$ ), with increasing concentrations of DODAB:MO (1:1) vesicles, showing the spectral decomposition into DNA (dashed line) and $\mathrm{H}_{2} \mathrm{O}$ bands (pointed line)
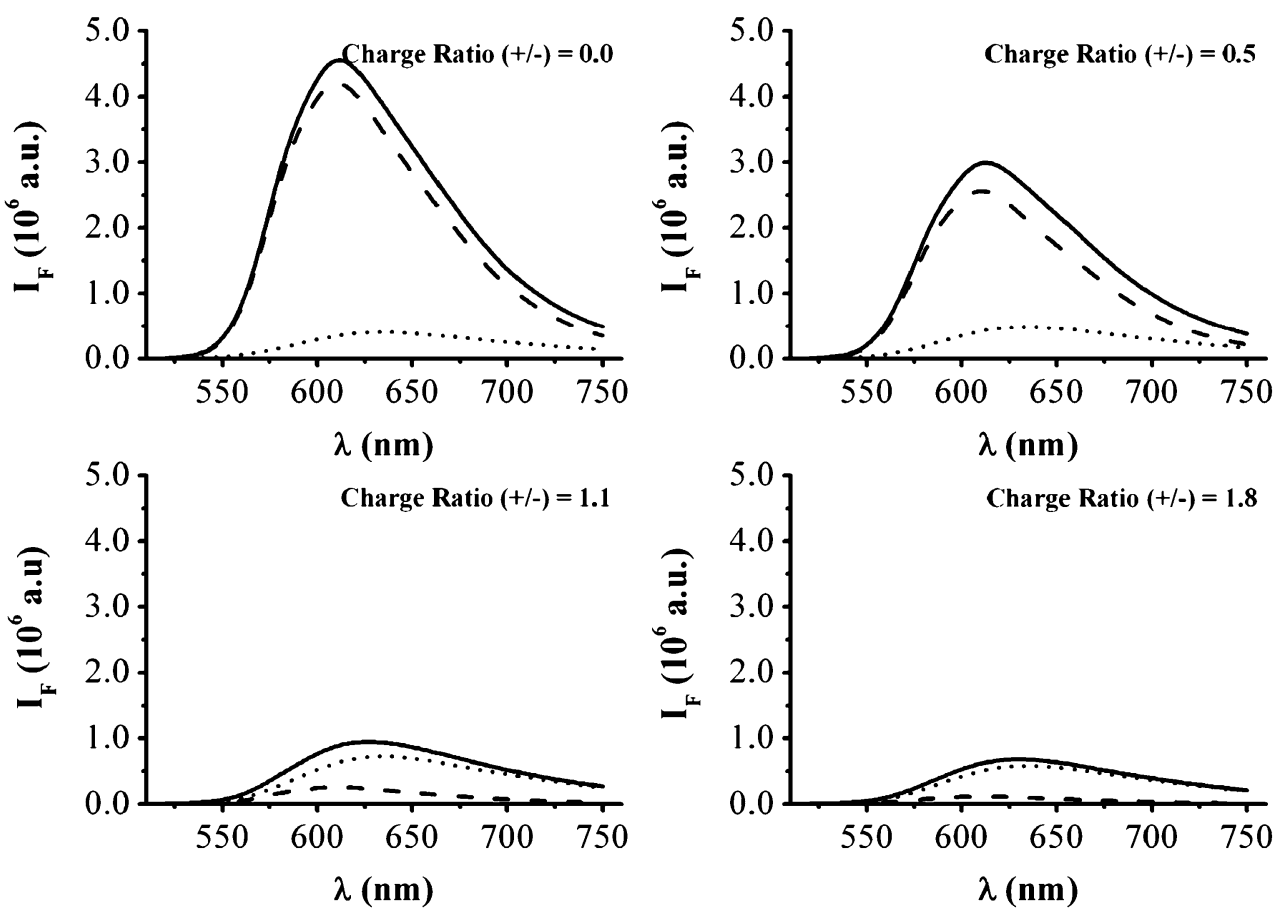

enhancement of the $\mathrm{H}_{2} \mathrm{O}$ band, confirming the condensation of DNA and the exclusion of EtBr to aqueous environment.

Figure 2 shows the evolution in the fluorescence intensities of the two fluorescence bands of EtBr in $\mathrm{H}_{2} \mathrm{O}$ environment and intercalated in DNA for pure DODAB and for different molar ratios of DODAB:MO (1:0.5, 1:1 and $1: 2)$, at different charge ratios $(+/-)$.

At lower charge ratio $(+/-)(<1.0)$, the relative proportion of MO seems to have an important role in the evolution process of DNA condensation, as seen by the different DNA condensation efficiencies $(\alpha)$ observed at charge ratios (+/-) 0.5 and 1.1 (Table 1). The system DODAB:MO $(1: 1)$ seems to be the one that more efficiently condenses DNA at charge ratio (+/-) 1.0 when compared with pure DODAB (at $25^{\circ}$ ). Oppositely, the similarity of the DNA complexation efficiencies $(\alpha)$ for the different systems at charge ratio $(+/-)=1.8$ (Table 1$)$, suggests that the amount of $\mathrm{MO}$ is not determinant in the final DNA condensation
Fig. 2 Variation of the decomposed fluorescence intensities of EtBr in DNA and $\mathrm{H}_{2} \mathrm{O}$ bands with charge ratio (+/-) increase, for the titration of different DODAB:MO systems presenting different molar ratios (squares $(1: 2)$, circles $(1: 1)$ and triangles (1:0.5)) and pure DODAB systems (upside-down triangles) to salmon sperm DNA solution $(20 \mu \mathrm{g} / \mathrm{ml})$

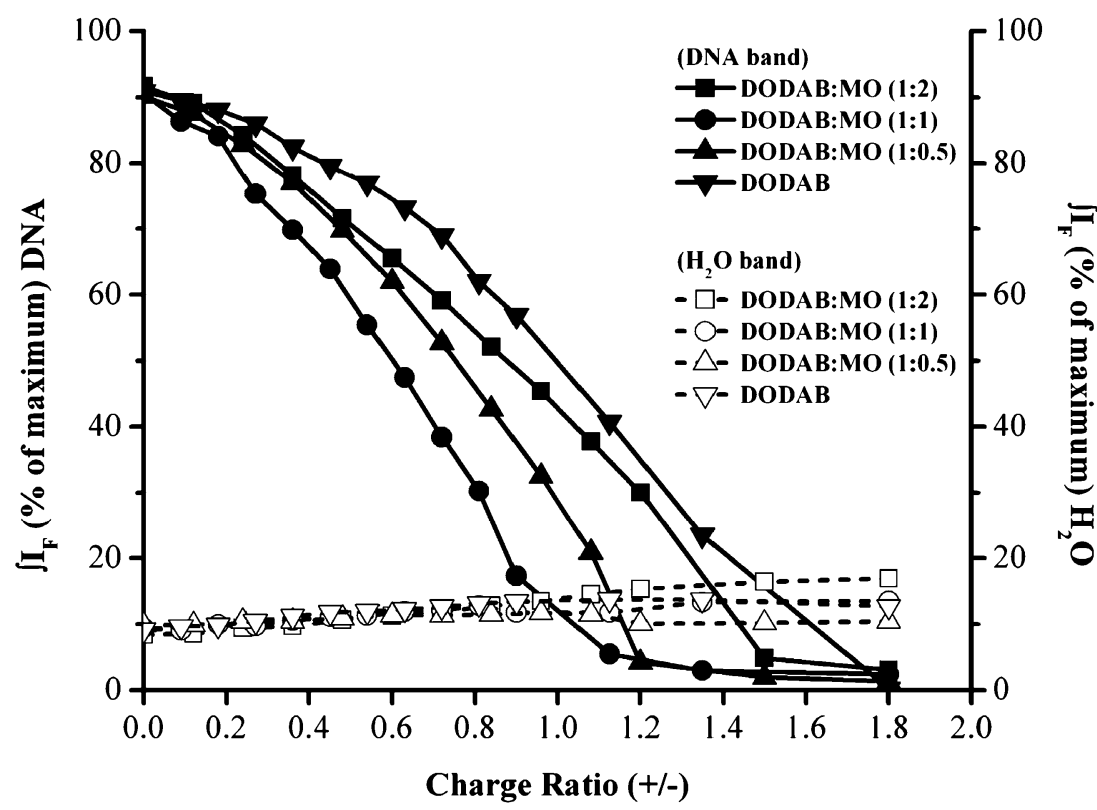


Table 1 Percentages of complexed DNA $(\alpha)$ at charge ratios $(+/-)$ $0.0,0.5,1.1$ and 1.8 , for the titration of different DODAB:MO systems presenting different molar ratios (1:2, 1:1, and 1:0.5) and pure DODAB systems $\left(25\right.$ and $\left.55^{\circ} \mathrm{C}\right)$ to salmon sperm DNA solution $(20 \mu \mathrm{g} / \mathrm{ml})$

\begin{tabular}{|c|c|c|c|c|}
\hline \multirow[t]{2}{*}{ Liposomes } & \multicolumn{4}{|c|}{$\%$ of Complexed DNA $(\alpha)$} \\
\hline & $\begin{array}{l}\text { R.C. } \\
(+/-) 0.0\end{array}$ & $\begin{array}{l}\text { R.C. } \\
(+/-) 0.5\end{array}$ & $\begin{array}{l}\text { R.C. } \\
(+/-) 1.1\end{array}$ & $\begin{array}{l}\text { R.C. } \\
(+/-) 1.8\end{array}$ \\
\hline $\begin{array}{l}\text { DODAB:MO } \\
(1: 2)\end{array}$ & 0.0 & 21.9 & 58.8 & 96.6 \\
\hline $\begin{array}{l}\text { DODAB:MO } \\
(1: 1)\end{array}$ & 0.0 & 38.8 & 93.9 & 97.3 \\
\hline $\begin{array}{l}\text { DODAB:MO } \\
(1: 0.5)\end{array}$ & 0.0 & 22.7 & 76.8 & 98.5 \\
\hline $\begin{array}{l}\text { DODAB } \\
\left(25^{\circ} \mathrm{C}\right)\end{array}$ & 0.0 & 15.4 & 55.2 & 99.8 \\
\hline $\begin{array}{r}\text { DODAB } \\
\left(55^{\circ} \mathrm{C}\right)\end{array}$ & 0.0 & 42.4 & 94.0 & 98.0 \\
\hline
\end{tabular}

efficiency leading to the lipoplex formation, but may be important in the morphology of the lipoplexes formed. It is observed that the rate of DNA condensation increases in order DODAB:MO (1:1) > DODAB:MO (1:0.5) > DODAB:MO (1:2)> DODAB.

It is known that an important effect of the mixture of monoacylglycerols with vesicles is the reduction of chain packing constraints by partitioning into the interstices in the hydrocarbon region. Monoacylglycerols also confer instability to DODAB liposomes due to its "curvature loving" properties
[20]. This fact may offer the opportunity for MO softening the DODAB lipid bilayer, decreasing its bending rigidity and so increasing the lateral mobility of the chain lipid.

This can explain the increase of DNA condensation efficiency with $\mathrm{MO}$ content, but an inversion is observed at higher MO molar ratio DODAB:MO (1:2). In order to gain further insights on the MO role on the lipoplex formation we have performed some $90^{\circ}$ SLS experiments and preliminary energy transfer studies.

$90^{\circ}$ static light scattering

The $90^{\circ}$ SLS is a good measure of relative changes in particle size [24]. It gives important information on size instability, which is one of the major factors in determining transfection efficiency in cell culture [1]. The SLS data were presented under the form $D / D_{0}$, where $D$ is the $90^{\circ}$ SLS after the addition of mixed cationic liposomes in the presence of DNA, and $\mathrm{D}_{0}$ is the $90^{\circ}$ SLS the in absence of DNA, at corresponding lipid concentration. Figure 3 presents the $D / D_{0}$ variation as a function of charge ratio $(+/-)$. The curves have a bell shape, reaching their highest values at charge ratios (+/-) between 0.7 and 1.1, the values being dependent on the liposome lipid composition.

Theoretical studies show that at the charge ratio region $(+/-)$ between 0.7 and 1.1, lipoplexes composed of "curvature-loving" helper lipids can have sandwich type $\left(L_{\alpha}^{C}\right)$ and inverted aggregates $\left(H_{I I}^{C}\right)$ [6]. Only when helper lipid content is higher than $50 \%$, the inverted structures are predicted. In our results, this corresponds to a shift in the $90^{\circ}$ SLS peak to lower charge ratios (+/-) and higher mean
Fig. 3 Variation of scattered light intensity $\left(D / D_{0}\right)$ with charge ratio (+/-) increase, for the titration of DNA with different DODAB:MO systems presenting different molar ratios (squares $(1: 2)$, circles $(1: 1)$ and triangles $(1: 0.5))$ and pure DODAB systems (upside-down triangles). $D / D_{0}$ represents the ratio between scattered light intensity $\left(\lambda_{\text {exc }}=600 \mathrm{~nm}, \lambda_{\text {emi }}=\right.$ $601 \mathrm{~nm}$ ) in the presence of DNA $(D)$ and scattered light intensity $\left(\lambda_{\text {exc }}=600 \mathrm{~nm}, \lambda_{\text {emi }}=601 \mathrm{~nm}\right)$ in the absence of DNA $\left(\mathrm{D}_{0}\right)$

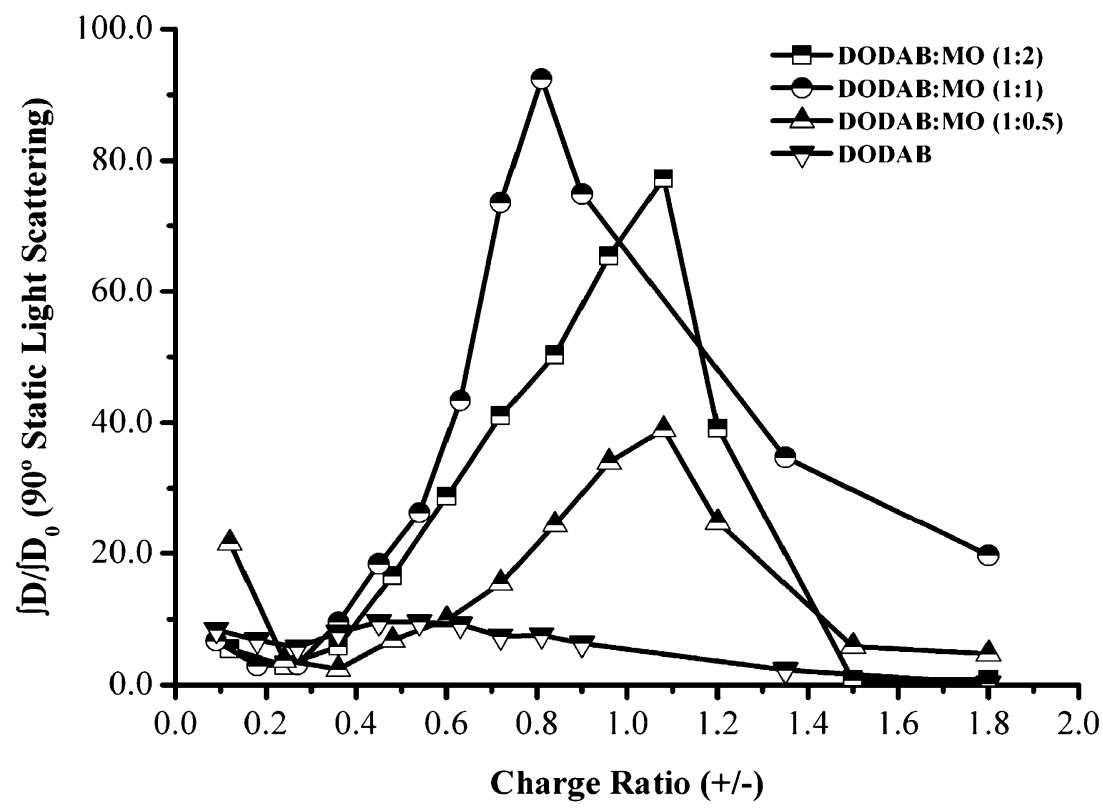


Fig. 4 Variation of the decomposed fluorescence intensities of $\mathrm{EtBr}$ in DNA and $\mathrm{H}_{2} \mathrm{O}$ bands with charge ratio (+/-) increase, for the titration of pure DODAB systems at different temperatures (triangles $\left(25^{\circ} \mathrm{C}\right)$, diamonds $\left(55^{\circ} \mathrm{C}\right)$ and arrowheads $\left(25{ }^{\circ} \mathrm{C}(0.0<\mathrm{C} . \mathrm{R}(+/-)<0.9)\right.$ to $\left.55{ }^{\circ} \mathrm{C}(0.0<\mathrm{C} . \mathrm{R}(+/-)<0.9)\right)$ to salmon sperm DNA solution $(20 \mu \mathrm{g} / \mathrm{ml})$

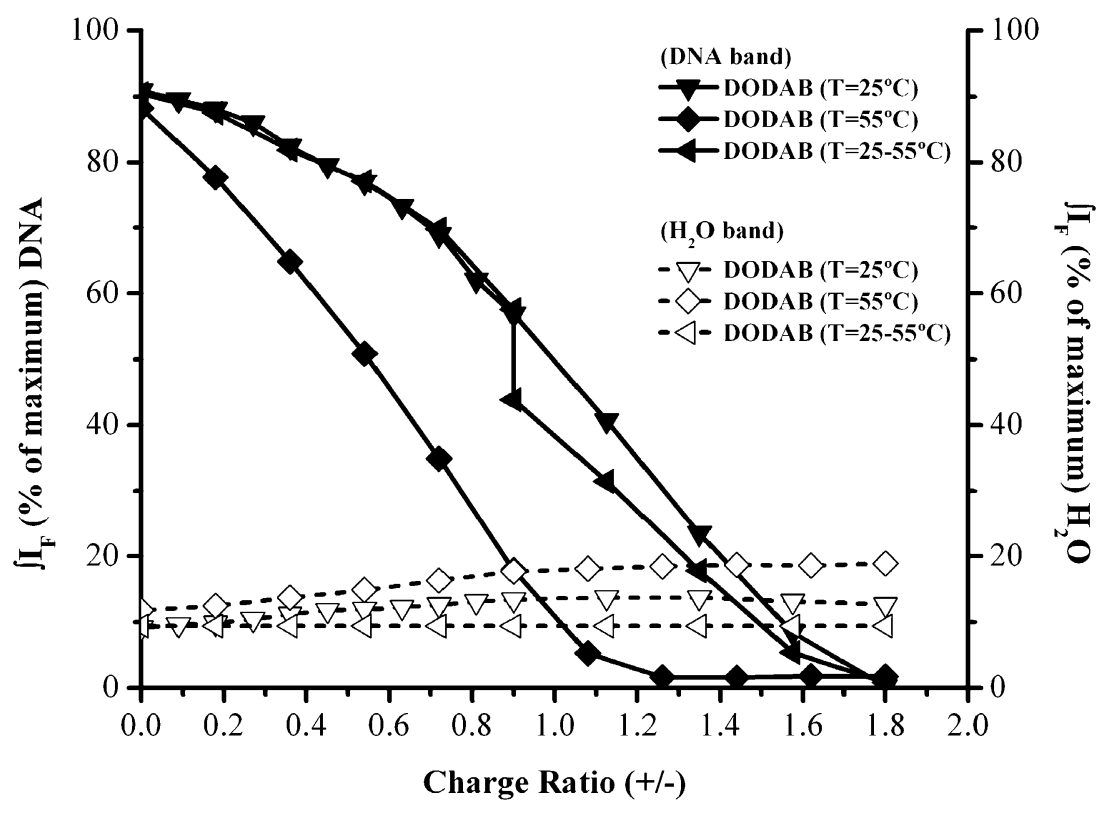

particle size (Fig. 3). Again an inversion is observed for the DODAB:MO system with the highest MO content, which is not expect for the theoretical calculations [6]. The formation of inverted structures is expected to exclude more efficiently the EtBr, confirming the results in the previous section. This suggests that an excess of MO does not promote inverted DNA structures as much as expected.

A possible explanation for the behavior at higher MO content is the coexistence of DODAB-MO inverted structures without DNA which, by being smaller, originate lower light scattering level. But, we can not rule out the possibility of being away from the thermodynamical equilibrium. To test this hypothesis, we have performed some studies with pure DODAB lipoplexes at two different temperatures, below and above DODAB melting tempera- ture $\left(T_{m} \approx 45^{\circ} \mathrm{C}\right)[29-32]$ (Fig. 4). Initially, it was promoted the DNA complexation at $25{ }^{\circ} \mathrm{C}$ until charge ratio (+/-) was 0.9. At this point, the temperature was increased to $55^{\circ} \mathrm{C}$ and then maintained throughout the rest of the titration. It was observed that the DNA complexation efficiency did not catch up the one obtained when the titration was performed at $55{ }^{\circ} \mathrm{C}$ since the beginning. This behaviour indicates that thermodynamical issues are not the only factors that explain the behaviour of lipolexes formation. There may be energetic barriers involved in the organization of the complexes.

Fluorescence resonance energy transfer

A third approach for assessing the direct effect of the MO as a helper on DODAB-DNA complexes (lipoplexes), was
Fig. 5 Normalized spectra of absorption of $\mathrm{EtBr}$ (dashed line) and fluorescence of DPHPC (straight line), showing the spectral overlapping (grey area) between donors emission and acceptors absorbance

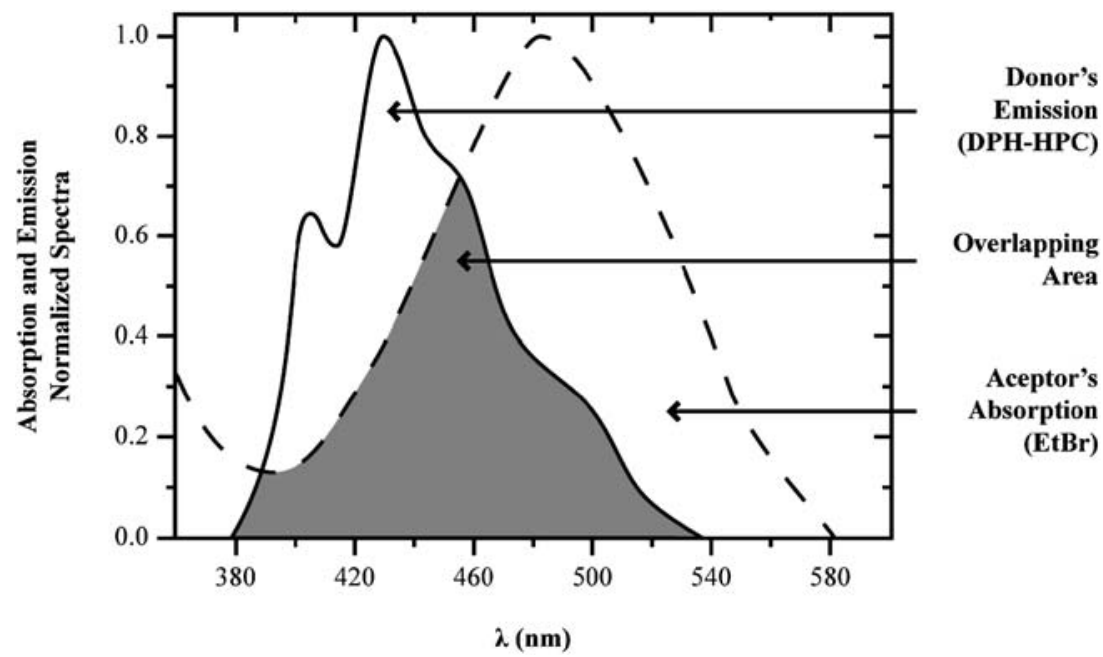


Fig. 6 Variation of fluorescence resonance energy transfer efficiency $\left(\Phi_{F R E T}\right)$ between DPH-HPC (donor) and EtBr (acceptor) with charge ratio $(+/-)$ increase, for the titration of different DODAB:MO systems presenting different molar ratios (squares $(1: 2)$, circles $(1: 1)$ and triangles $(1: 0.5))$ to salmon sperm DNA solution $(20 \mu \mathrm{g} / \mathrm{ml}) . \Phi_{F R E T}$ represents the ratio between DPH-HPC emission $\left(\lambda_{\mathrm{exc}}=390 \mathrm{~nm}\right)$ in the presence of $\operatorname{EtBr}\left(I_{F(D A)}\right)$ and DPH-HPC emission $\left(\lambda_{\text {exc }}=\right.$ $390 \mathrm{~nm})$ in the absence of $\mathrm{EtBr}$ $\left(I_{F(D)}\right)$

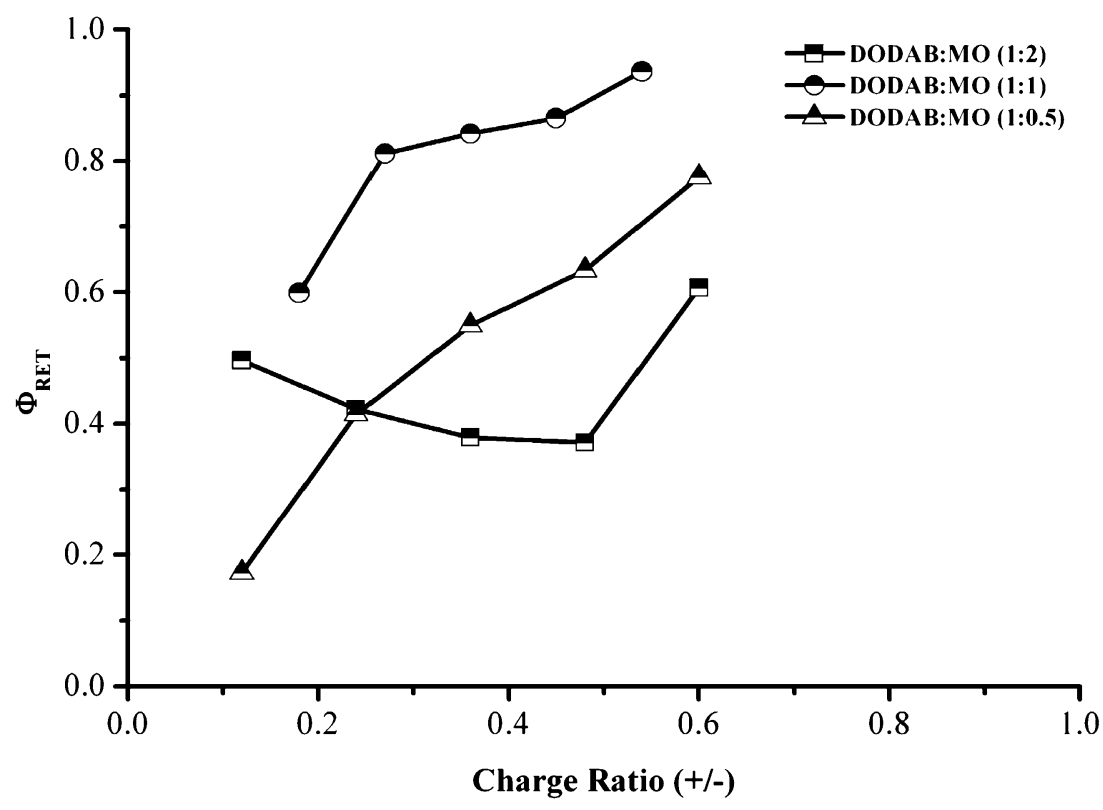

based on fluorescence energy transfer (FRET). For these experiments, the choice of the donor-acceptor pair was based in the fact of the emission spectra of the probe DPH$\mathrm{PE}$ strongly overlaps the EtBr absorption spectrum, which is an essential FRET requirement (Fig. 5).

Figure 6 shows the efficiency of resonance energy transfer for DODAB:MO (1:2), (1:1) and (1:0.5) at different charge ratios $(+/-)$. We observed a very significant enhancement in $\Phi_{F R E T}$ when MO is increased from DODAB:MO $(1: 0.5)$ to DODAB:MO (1:1). As referred previously, this increase corresponds to the appearance of inverted lipoplexes structures. These are much more compact than the sandwich type ones [6], which leads to a lower mean donor-acceptor distance. As in the previous methods, an inversion occurs in the DODAB:MO (1:2) systems. This could be explained by the solubilization of the DPH-HPC in the mentioned plain DODAB/MO inverted structures.

\section{Conclusions}

Our results demonstrate that the inclusion of monoolein in the cationic liposomes formulation significantly modifies the rate of DNA complexation, being DODAB:MO (1:1) the system with higher DNA condensation efficiency. The $90^{\circ}$ SLS and FRET assays suggest the existence of inverted structures due to the presence of monoolein, which may be of importance to the transfection process. These inverted structures can be different from the usual hexagonal morphology because the $\mathrm{MO}$ has a tendency to form inverted cubic phases [19]. In further work, we will try to observe these inverted structures using structural characterization techniques. The existence of proposed inverted structures without DNA would also be confirmed. Cell transfection efficiency and citotoxicity studies are currently underway.

Acknowledgements The authors would like to thank to FCT-Portugal for funding through Centro de Física of Universidade do Minho.

\section{References}

1. Taira K, Kataoka K, Niidome T (2005) Non-viral gene therapy: gene design and delivery, 1st edn. Springer Verlag Editions, Tokyo, p 490

2. Felgner PL, Gadek TR, Holm M, Roman R, Chan HW, Wenz M, Northrop JP, Ringold RM, Danielson M (1987) Lipofection: a highly efficient, lipid-mediated DNA-transfection procedure. Proc Natl Acad Sci U S A 84:7413-7417

3. Lasic DD, Papahadjopoulos D (1998) Medical applications of liposomes, 1st edn. Elsevier Editions, New York, p 779

4. Zuhorn IS, Hoekstra D (2002) On the mechanism of cationic amphiphile-mediated transfection. To fuse or not to fuse: is that the question? J Membr Biol 189:167-179

5. Maslov MA, Syicheva EI, Morozova NG, Serebrennikova GA (2000) Cationic amphiphiles of both lipid and nonlipid nature in gene therapy. Russ Chem Bull 49(3):385-401

6. May S, Ben-Shaul A (2004) Modeling of cationic lipid-DNA complexes. Curr Med Chem 11:151-167

7. Zabner J (1997) Cationic lipids used in gene transfer. Adv Drug Deliv Rev 27:17-28

8. Zhang Y, Anchordoquy TJ (2004) The role of lipid charge density in the serum stability of cationic lipid/DNA complexes. Biochim Biophys Acta 1663:143-157 
9. Pector V, Backmann J, Maes D, Vandenbranden M, Ruysschaert J (2000) Biophysical and structural properties of DNA-diC14amidine complexes - effect of the DNA-lipid ratio. J Biol Chem 275:29533-29538

10. Marques BF, Schneider JW (2006) Effect of electrostatic interactions on binding and retention of DNA. Colloids Surf B Biointerfaces 53:1-8

11. Simberg D, Danino D, Talmon Y, Minsky A, Ferrari ME, Wheeler CJ, Barenholz Y (2001) Phase behaviour, DNA ordering and size instability of cationic lipoplexes. J Biol Chem 26:47453-47459

12. Gonçalves E, Debs RJ, Heath TD (2004) The effect of liposome size on the final lipid-DNA ratio of cationic lipoplexes. Biophys J $86: 1554-1563$

13. Madeira C, Loura LMS, Prieto M, Fedorov A, Aires-Barros MR (2007) Liposome complexation efficiency monitored by FRET effect of charge ratio, helper lipid and plasmid size. Eur Biophys J 36:609-620

14. Kichler A, Zauner W, Ogris M, Wagner E (1998) Influence of the DNA complexation medium on the transfection efficiency of lipospermine/DNA particles. Gene Ther 5(6):855-890

15. Koynova R, MacDonald RC (2005) Lipid transfer between cationic vesicles and lipid-DNA lipoplexes: Effect of serum. Biochim Biophys Acta 1714:63-70

16. Hui SW, Langner M, Zhao Y, Ross P, Hurley E, Chan K (1996) The role of helper lipids in cationic liposome-mediated gene transfer. Biophys J 71:590-599

17. Koynova R, MacDonald RC (2003) Mixtures of cationic lipid Oethylphosphatidylcholine with membrane lipids and DNA: Phase diagrams. Biophys J 85:2449-2465

18. Barreleiro PCA (2001) Equilibrium and kinetic studies of the binding of DNA to cationic liposomes. PhD thesis, Physical Chemistry Department, Center for Chemistry and Chemical Engineering, Lund University, Sweden

19. Lipowsky R, Sackmann E (1995) Structure and dynamics of membranes, 2nd edn. Elsevier Editions, New York, p 957

20. Ulrich AS (2002) Biophysical aspects of using liposomes as delivery vehicles. Biosci Rep 22:129-150
21. Wolfbeis OS (2005) Fluorescence spectroscopy in biology: Advanced methods and their applications to membranes. Proteins, DNA, and cells, 1st edn. Springer, Berlin, p 315

22. Lilley DMJ, Wilson TJ (2000) Fluorescence resonance energy transfer as a structural tool for nucleic acids. Curr Opin Chem Biol 4:507-517

23. Zhang Y, Garzon-Rodriguez W, Manning MC, Anchordoquy TJ (2003) The use of fluorescence resonance energy transfer to monitor dynamic changes of lipid-DNA interactions during lipoplex formation. Biochim Biophys Acta 1614:182-192

24. Holmberg K (2002) Applied surface and colloid chemistry - vol 2, 1st edn. Wiley, New York, p 501

25. Stephenson FW (2003) Calculations in molecular biology and biotechnology, 1st edn. Academic, San Diego, p 315

26. Barreleiro PCA, Lindman B (2003) The kinetics of DNA-cationic vesicle complex formation. J Phys Chem B 107:6208-6213

27. Scaria PV, Shafer RH (1991) Binding of ethidium bromide to a DNA triple helix. Evidence for intercalation. J Biol Chem 266 (9):5417-5423

28. Siano DB, Metzler DE (1969) Band shapes of the electronic spectra of complex molecules. J Chem Phys 51(3):1856-1861

29. Hungerford G, Baptista ALF, Coutinho PJG, Castanheira EMS, Real Oliveira MECD (2006) Interaction of DODAB with neutral phospholipids and cholesterol studied using fluorescence anisotropy. J Photochem Photobiol A 181:99-105

30. Feitosa E, Brown W (1997) Fragment and vesicle structures in sonicated dispersions of dioctadecyldimethylammonium bromide. Langmuir 13:4810-4816

31. Feitosa E, Alves FR, Niemiec A, Real Oliveira MECD, Castanheira EMS, Baptista ALF (2006) Cationic liposomes in mixed didodecyldimethylammonium bromide and dioctadecyldimethylammonium bromide aqueous dispersions studied by differential scanning calorimetry, nile red fluorescence, and turbidity. Langmuir 22:3579-3585

32. Feitosa E, Barreleiro PCA, Olofsson G (2000) Differential scanning calorimetry studies of cationic vesicles prepared by different methods. Chem Phys Lipids 105:201-213 